This document is the Accepted Manuscript version of a Published Work that appeared in final form in Journal of Organic Chemistry, copyright (c) American Chemical Society after peer review and technical editing by the publisher. To access the final edited and published work see: https://dx.doi.org/10.1021/acs.joc. 7b01431. 


\section{Polyamide-Polyamine Cryptand as Dicarboxylate Receptor: Dianion Binding Studies in the Solid State, in Solution, and in the Gas Phase}

Sourav Chakraborty†‡ Subrata Saha†‡ Luís M. P. Lima§ Ulrike Warzok $\perp$ Sayan

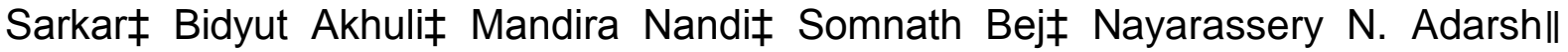
Christoph A. Schalley* $\perp$ Rita Delgado*§ Pradyut Ghosh $\ddagger$

‡ Department of Inorganic Chemistry, Indian Association for the Cultivation of Science, 2A \& 2B Raja S. C. Mullick Road, Kolkata - 700032, India

$\S$ Instituto de Tecnologia Química e Biológica António Xavier, Universidade Nova de Lisboa, Avenida da República, 2780-157 Oeiras Portugal

$\perp$ Institut für Chemie und Biochemie, Freien Universität Berlin, Takustrasse 3, 14195 Berlin (Germany)

II Institut Catala de Nanociencia i Nanotecnologia (ICN2), Edifici ICN2, Campus UAB, Cerdanyola del Valles 08193, Spain

\section{ABSTRACT}

Polyamide-polyamine hybrid macrobicycle $L$ is explored with respect to its ability to bind $\alpha, \omega$-dicarboxylate anions. Potentiometric studies of protonated $L$ with the series of dianions from succinate (suc2-) through glutarate (glu2-), a-ketoglutarate (kglu2), adipate (adi2-), pimelate (pim2-), suberate (sub2-), to azelate (aze2-) have shown adipate preference with association constant value of $K=4900 M-1$ in a H2O/DMSO (50:50 v/v) binary solvent mixture. The binding constant increases from glu2- to adi2- and then continuously decreases with the length of the anion chain. Further, potentiometric studies suggest that hydrogen bonding between the guest anions and the amide/ammonium protons of the receptor also contributes to the stability of the associations along with electrostatic interactions. Negative-mode electrospray ionization of aqueous solutions of host-guest complexes shows clear 
evidence for the selective formation of 1:1 complexes. Single-crystal X-ray structures of complexes of the receptor with glutaric acid, a-ketoglutaric acid, adipic acid, pimelic acid, suberic acid, and azelaic acid assist to understand the observed binding preferences. The solid-state structures reveal a size/shape complementarity between the host and the dicarboxylate anions, which is nicely reflected in the solution state binding studies.

\section{INTRODUCTION}

Recognition of dicarboxylate anions by synthetic receptors has received increasing attention over the last few decades,(1-11) as this class of anionic substrates is pivotal in many biological and environmental processes.(12) Dicarboxylate anions are critical components of numerous metabolic processes like the Krebs cycle, and analysis of this class of anions in biological systems can provide useful information about neurological and metabolic diseases.

Synthetic receptors for dicarboxylate recognition are mostly acyclic or macrocyclic compounds with amine or amide functionalities.(13-26) Nevertheless, macrobicycles are likely advantageous because of their preorganization and encapsulation properties within a well-defined cavity, which eventually lead to better guest selectivity.(26-37) In this respect, polyamine-based ditopic macrobicyclic receptors have been studied with dicarboxylate guests, either in protonated state or as a dinuclear complex to form cascade species. In the protonated state, the polyammonium sites of the macrobicyclic receptor provides binding sites for strong electrostatic interactions and hydrogen bonding with the dianionic guest in aqueous medium.(38-45) To achieve strong binding of the dianionic guest, these receptors need to possess several positively charged ammonium binding sites arranged 
around a cavity. Thus, strongest binding occurs usually with the fully protonated form of the polyamine receptors. On the other hand, dicarboxylates only exist as dianionic species in a relatively narrow $\mathrm{pH}$ window, which limits the utility of the polyamines in their fully protonated state. In the above-mentioned cascade complexes instead, dicarboxylates can be coordinated between the metal centers of a dinuclear complex of a ditopic polyamine macrobicycle.(46-48) However, the strong metal coordination of the anionic guest in these complexes often kinetically hampers the reversibility of binding, which is important for extraction and transport applications. On the other hand, amide-based anion receptors continue to attract attention in supramolecular chemistry, because of the ease of their synthesis and biological precedence.(49-55) However, dicarboxylate receptors with amide functionalities are less explored in aqueous solvents due to their poor solubility in this solvent.(16, 56-59) As a proof of concept, herein we have investigated the macrobicyclic receptor $L$ (Figure 1) containing amides as well as protonatable amines for dicarboxylate recognition in H2O/DMSO (50:50 v/v) solvent medium as a hybrid receptor of which we hope that it combines the advantages of both types of receptors.

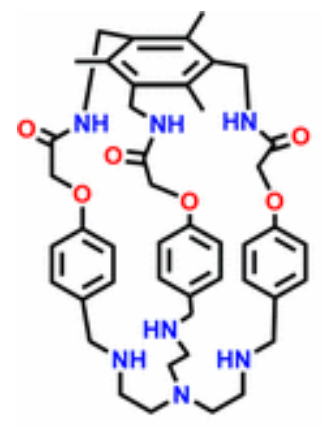

$\mathbf{L}$
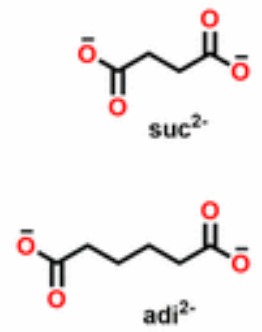

adi $^{2-}$<smiles>O=C(O)CCCC(=O)O</smiles><smiles>O=C(O)CCCCCCC(=O)O</smiles>

pim $^{2+}$<smiles>[2H]C(=O)CCCCCCCC(=O)O</smiles>

$a^{2 *}$<smiles>O=C(O)CCC(=O)C(=O)O</smiles><smiles>O=C(O)CCCCCCCC(=O)O</smiles>

Figure 1. Chemical structures of the studied macrobicycle, L, and dicarboxylate anions. 
Recently, we have studied heteroditopic macrobicycle, $L$, that is composed of preorganized amide and amine clefts, in each of which anions of different sizes can bind in the receptor's protonated state and in polar solvents.(60) These two wellseparated binding sites are expected to cooperate for encapsulating dianionic guests within the cavity of the receptor. This heteroditopic hybrid host with trisamide and tetramine functionalities could be advantageous for its reduced number of protonated sites compared to octaamine cryptands. Combinations of both hydrogen-bonding (ammonium and amide) and electrostatic interactions (ammonium) might show a different solubility/anion recognition pattern compared to purely polyammonium- or polyamide-based analogues. It would therefore be interesting to further explore this receptor for recognition of dicarboxylate anions in aqueous medium. In this respect, linear aliphatic dicarboxylates, ${ }^{-} \mathrm{OOC}-(\mathrm{CH} 2) n-\mathrm{COO}^{-}$, with sufficiently long spacers could be well deserving candidates. In fact, these dicarboxylates may be encapsulated in several different binding modes in the rather large cavity of $L$. Therefore, in this work we explore the amide-ammonium macrobicycle $L$ for binding of linear aliphatic dicarboxylate substrates $(n=2-7)$ in solution, in the solid state and in the gas phase.

\section{RESULTS AND DISCUSSION}

\section{Binding Studies of Host (HiLi+) with the Studied Anionic Guests (HaAa-2)}

The binding constants of the protonated forms of $L$, as the receptor, and the dicarboxylate anionic guests, suc2-, glu2-, kglu2-, adi2-, pim2-, sub2-, and aze2were determined in a H2O:DMSO $(50: 50 \mathrm{v} / \mathrm{v})$ solvent mixture at $25.0{ }^{\circ} \mathrm{C}$ and ionic strength $0.10 \mathrm{M}$ in $\mathrm{NaClO} 4$. Typical titrations were carried out by addition of a strong 
base (standard $\mathrm{KOH}$ solution) to solutions containing known concentrations of $\mathrm{L}$ and the anion, at different receptor:anion ratio. In these titrations, the change of potential ( $\mathrm{E}$ in $\mathrm{mV}$, after being converted to $\mathrm{pH}$ ) was monitored as a function of the added titrant. The collected data were used to determine the equilibrium constants, (see Experimental Section below). The stepwise association constants and the corresponding equilibrium reactions are collected in Table 1, whereas the overall association constants are listed in Table S1. The protonation constants of $L$ and of all anionic guests were determined under the same experimental conditions and are compiled in Table S2.

Table 1. Stepwise (KHhLA) Association Constants of the Protonated Species of $L$ (HiLi+) with the Various Guests (H2A) in H2O:DMSO (50:50 v/v) Solution at $25.0^{\circ} \mathrm{C}$ and $\mathrm{I}=0.10 \mathrm{M}$ in $\mathrm{NaClO} 4$

\begin{tabular}{|c|c|c|c|c|c|c|c|}
\hline \multirow[b]{2}{*}{ equilibrium reaction } & \multicolumn{7}{|c|}{$K_{\mathrm{H}, \mu \mathrm{H}}$} \\
\hline & $\operatorname{suc}^{2-}$ & $\mathrm{glu}^{2-}$ & $\mathrm{kglu}^{2-}$ & $\mathrm{adi}^{2-}$ & pim $^{2-}$ & sub $^{2-}$ & $a x e^{2-}$ \\
\hline $\mathrm{H}_{3} \mathrm{~L}^{3+}+\mathrm{HA}^{-} \rightleftarrows \mathrm{H}_{4} \mathrm{LA}^{2+}$ & 3550 & 510 & 870 & 4900 & 1510 & 660 & \\
\hline $\mathrm{H}_{3} \mathrm{~L}^{3+}+\mathrm{A}^{2-} \rightleftarrows \mathrm{H}_{3} \mathrm{LA}^{+}$ & 2100 & 1200 & 1290 & 8510 & 2040 & 1260 & 1120 \\
\hline $\mathrm{H}_{2} \mathrm{~L}^{2+}+\mathrm{A}^{2-} \rightleftarrows \mathrm{H}_{2} \mathrm{LA}$ & & 250 & 560 & 2400 & 500 & 250 & 300 \\
\hline $\mathrm{HL}^{+}+\mathrm{A}^{2-} \rightleftarrows \mathrm{HLA}^{-}$ & & & 200 & 2100 & & & \\
\hline $\mathrm{L}+\mathrm{A}^{2-} \rightleftarrows \mathrm{LA}^{2-}$ & & & & 1600 & & & \\
\hline
\end{tabular}

The host interacts with all anionic guests forming species with different protonation states, all of them in 1:1 host:guest stoichiometry. This implies that the host and each anion participate in several overlapping equilibria in different protonated forms. The stepwise equilibria can be unambiguously established for each case by determination of the effective binding constants (Keff) as a function of the $\mathrm{pH} .(61$, 62) The Keff value is defined as the quotient between the total amount of supramolecular species formed (sum of the concentrations of the entities formed between the various protonated forms of $L$ and the different protonated forms of the anions), and the product of the total concentration of the free host and the total 
concentration of the free guest species at a given $\mathrm{pH}$ : Keff $=\sum[\mathrm{HhLA}] / \Sigma[\mathrm{HaA}] \times$ $\sum[\mathrm{HiL}](\mathrm{h}=0-5(\mathrm{a}+\mathrm{i}), \mathrm{a}=0-2$ and $\mathrm{i}=0-3)$, where $\mathrm{L}$ is the deprotonated host and $\mathrm{A}$ is the anion. The plot obtained for our case is shown in Figure 2.

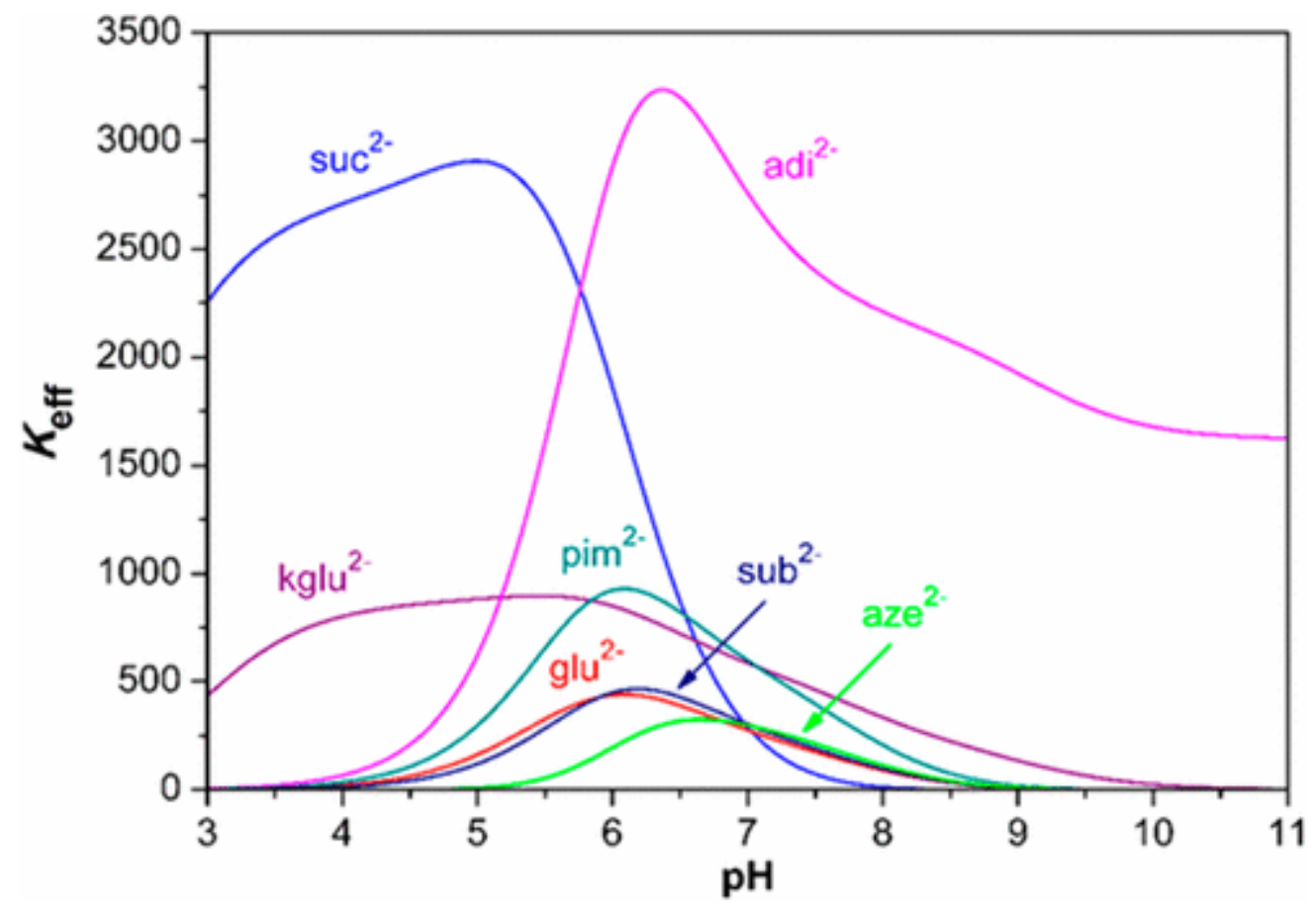

Figure 2. Plot of Keff values as a function of the $\mathrm{pH}$ for the association species formed between the HiLi+ receptor with each of the studied anions (HaAa-2). Creceptor $=$ Canion $=1.0 \mathrm{mM}$. For simplicity, each curve is identified with the abbreviation of the dianion.

As clearly shown in the diagram of Keff values as a function of $\mathrm{pH}$, the largest value was obtained for the adi2- dianion at a $\mathrm{pH}$ of 6.5 . It can also be seen from Table 1 that this anion exhibits larger binding constants and forms the most complete system of supramolecular species. In fact, the binding constants increase from glu2- to adi2- and then continuously decrease with the length of the chain between the two carboxylates until the end of the series is investigated. A different binding behavior is 
observed for suc2-, probably due to its shorter size, but maxima of Keff values are only slightly lower than those of adi2- and shifted toward the acidic region. The same happens with kglu2- but with much lower Keff values.

As usually found for the association of anions with polyammonium hosts, the binding constants increase with increasing positive charge on the host and increasing negative charge on the anionic guest, reflecting the importance of electrostatic interactions (see Table 1). However, in the presently studied host, important contributions from hydrogen bonding interactions need to be taken into account, especially in the case of adipate, pimelate, and $\alpha$-ketoglutarate.

\section{ESI-MS Studies of L with Dicarboxylic Acid Guests}

Negative-mode electrospray ionization of aqueous solutions of $L$ with the dianions of succinic acid, glutaric acid, a-keto glutaric acid, adipic acid, pimelic acid, suberic acid, and azelaic acid resulted in mass spectra showing singly deprotonated 1:1 complexes [L+Hacid- ] at $\mathrm{m} / \mathrm{z}$ 908, 922, 936, 936, 950, 964, and 978, respectively (Figure 3). In addition, signals of varying intensities can be assigned to the free $L$ as the singly deprotonated species and the chloride adduct at m/z 790 and 826 , respectively. Note that ESI measurements were also conducted in positive ionization mode, yet no peaks corresponding to L-acid assemblies could be observed. Traveling-wave ion mobility-mass spectrometry (TW-IMS) was applied to further study the assemblies in the gas phase. However, the obtained results are inconclusive regarding the gas-phase conformation of the assemblies (see the Supporting Information for a more detailed discussion). 


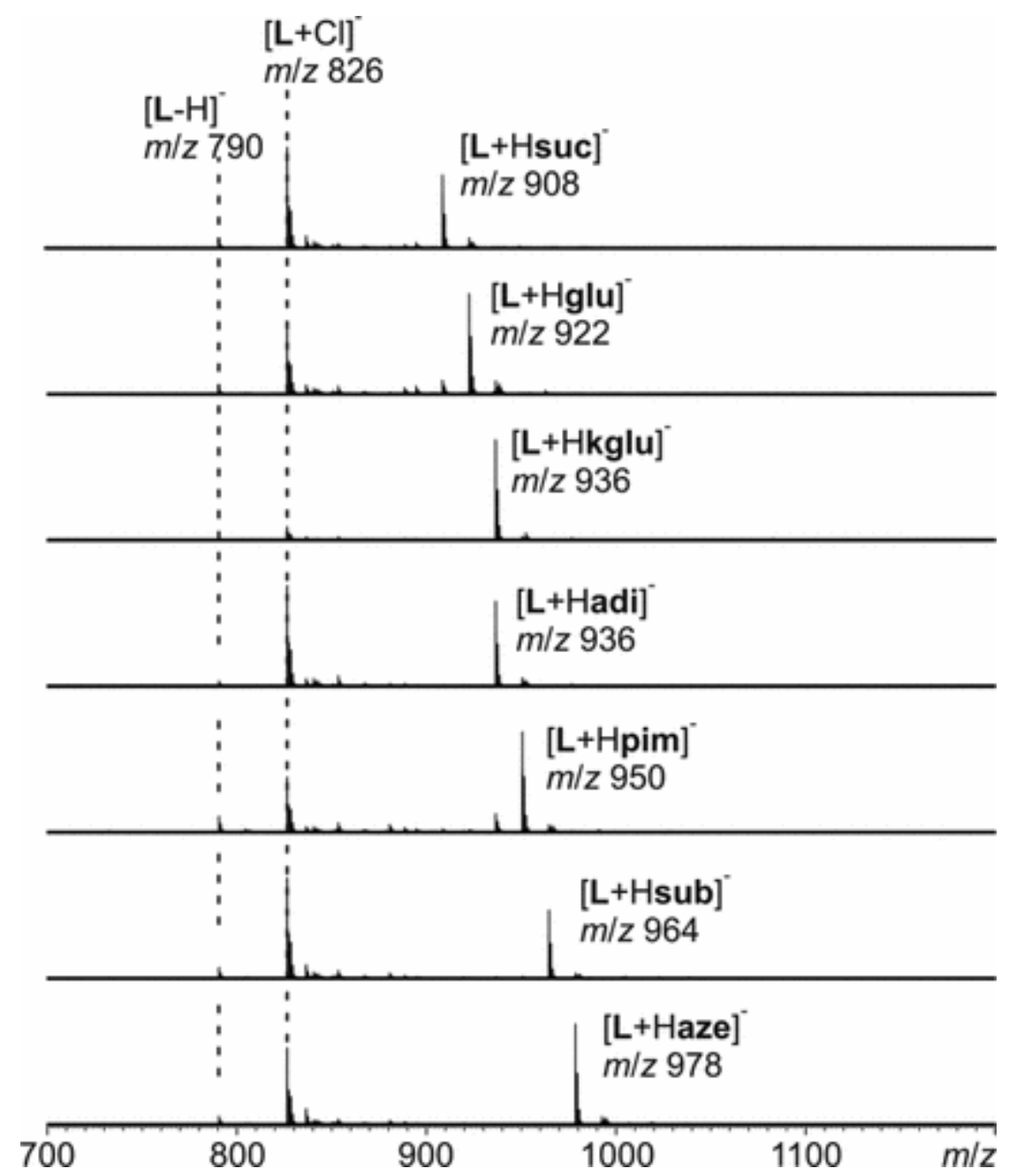

Figure 3. ESI-Q-TOF-HRMS spectra of assemblies of $L$ with succinic acid, glutaric acid, a-ketoglutaric acid, adipic acid, pimelic acid, suberic acid, and azelaic acid (100 $\mu \mathrm{M}$ in $\mathrm{H} 2 \mathrm{O} / \mathrm{MeOH} / \mathrm{CH} 2 \mathrm{Cl} 2$ 95:4:1).

\section{Single-Crystal Solid-State Structures}

To obtain more detailed structural insight, host-guest complexes 1-6 of $L$ with the dianions of a-keto glutaric acid, glutaric acid, adipic acid, pimelic acid, suberic acid and azelaic acid respectively were successfully crystallized by slow evaporation in $\mathrm{CH} 3 \mathrm{OH} / \mathrm{H} 2 \mathrm{O}$ solvent mixture. Host-guest complex 1 crystallized in a monoclinic space group P21/c. The asymmetric unit of 1 contains a triply protonated 
macrobicycle, $[\mathrm{H} 3 \mathrm{~L}] 3^{+}$, two $\alpha$-ketoglutarate ions and eight water molecules as the solvent of crystallization. Structural analysis of 1 reveals triprotonated $L$ with complete encapsulation of one a-ketoglutarate ion inside the cavity and the other is outside, in which one is monoanionic and the other is dianionic form in agreement with the charge balance of the species. The carboxylate $\mathrm{O}$ atoms $(\mathrm{O} 7, \mathrm{O})$ of the encapsulated guests are stabilized by $\mathrm{N}-\mathrm{H} \cdots \mathrm{O}[\mathrm{N} \cdots \mathrm{O}=3.044(5)-3.052(5) \AA ; \angle \mathrm{N}-$ $\left.\mathrm{H} \cdots \mathrm{O}=150-154^{\circ}\right]$ hydrogen bonding with the amide $(\mathrm{N} 1, \mathrm{~N} 3)$ functionalities of the triprotonated $L$ (Figure 4a, d). The other carboxylate anion (O9) exhibits hydrogen bonding with one of the ammonium proton (N4) $[\mathrm{N} \cdots \mathrm{O}=2.883(5) \AA ; \angle \mathrm{N}-\mathrm{H} \cdots \mathrm{O}=$ $\left.163^{\circ}\right]$. 


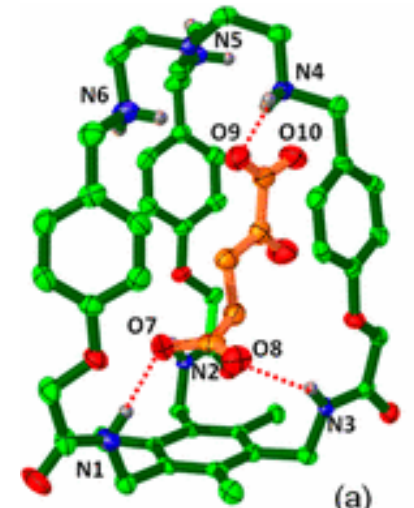

(a)

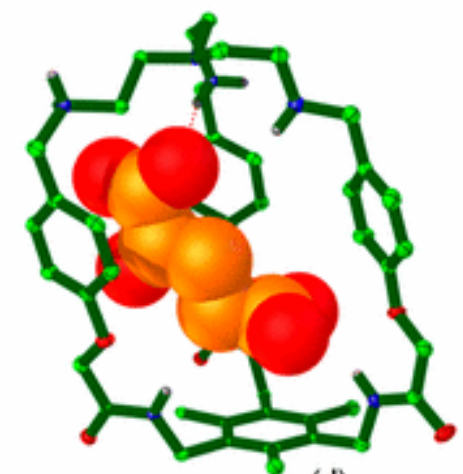

(d)

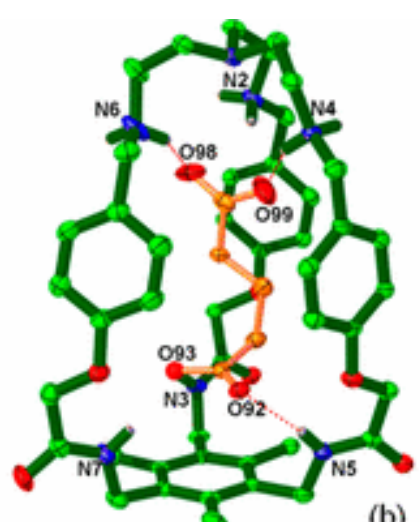

(b)

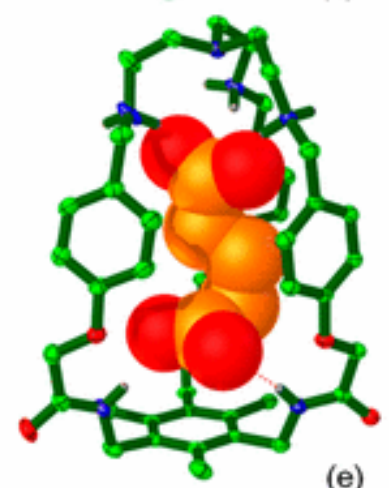

(e)

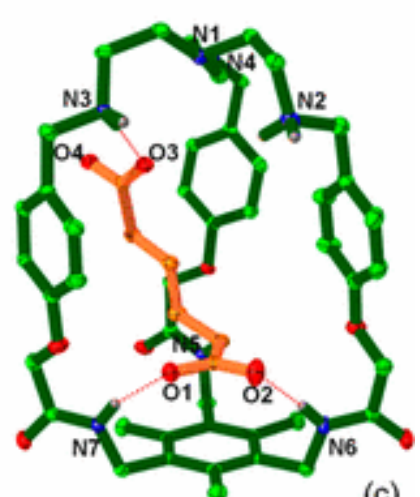

(c)

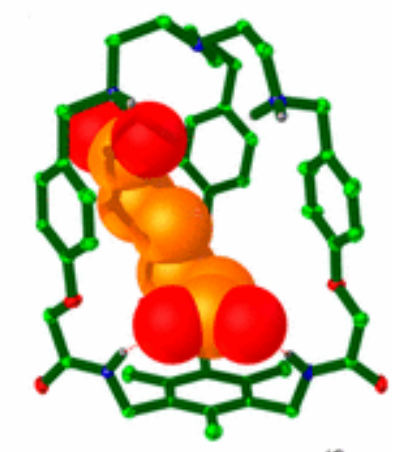

(f)

Figure 4. Single-crystal X-ray structures (in ellipsoid model) of complex (a) 1; one $\alpha$ keto glutarate is in the cavity of $[\mathrm{H} 3 \mathrm{~L}] 3+$. (b) 2 ; one glutarate is in the cavity of $[\mathrm{H} 3 \mathrm{~L}] 3+$. (c) 3; one adipate is in the cavity of $[\mathrm{H} 3 \mathrm{~L}] 3+$. (d-f) Encapsulated guests are shown in space-filling representation, respectively. Dicarboxylate guest and water molecules outside the receptor cavity are omitted for clarity.

A similar binding phenomenon is also observed in the case of single crystal X-ray structure of 2 (crystallized in a monoclinic space group C2/c), in which triprotonated $L$ is associated with two glutarate ions. The asymmetric unit consists of a triprotonated macrobicycle, $[\mathrm{H} 3 \mathrm{~L}] 3+$, two glutarate ions and nine water molecule as the solvent of crystallization. One of the glutarate anions is encapsulated within the cavity of the macrobicycle sustained by $\mathrm{N}-\mathrm{H} \cdots \mathrm{O}$ interactions involving the glutarate anions with the protonated amine and amide functionalities $[\mathrm{N} \cdots \mathrm{O}=2.705(5)-$ 
3.205(11) $\AA ; \angle \mathrm{N}-\mathrm{H} \cdots \mathrm{O}=154-166^{\circ}$ ] (Figure 4b, e). It is worthwhile to mention here that the glutarate anions are found to be disordered over two positions (Figure S15).

The crystal structure of 3 (monoclinic P21/c) is assembled from an asymmetric unit containing triprotonated host, 1.5 adipate anion and 17 water molecules. Structural analysis shows that one adipate anion is completely encapsulated in the receptor cavity and the other one is outside in a special position (inversion center) having $50 \%$ occupancy to the asymmetric unit. Oxygen atoms $(\mathrm{O} 1, \mathrm{O} 2)$ of the encapsulated adipate anions in the amide cleft are hydrogen bonded with amide protons (N7, N6) and $-\mathrm{NH} 2+-(\mathrm{N} 3)$ of the macrobicycle via $\mathrm{N}-\mathrm{H} \cdots \mathrm{O}$ interaction $[\mathrm{N} \cdots \mathrm{O}=2.857(4)-$ 2.892(5) $\AA$; $\angle \mathrm{N}-\mathrm{H} \cdots \mathrm{O}=161-163^{\circ}$ ] (Figure 4c, f). Importantly, the hydrogen bond distances of the encapsulated adipate in the amide and ammonium clefts are shorter than those of $\alpha$-ketoglutarate ion in 1 and of glutarate ion in 2 .

Similar to complex 1, pimelate-associated receptor in complex 4 contains an asymmetric unit of triprotonated receptor $[\mathrm{H} 3 \mathrm{~L}] 3+$ with two pimelate ions in monoanionic and dianionic states and seven water molecules. There are only two hydrogen bonding interactions observed between the receptor and the encapsulated guest (Figure 5a, d). 

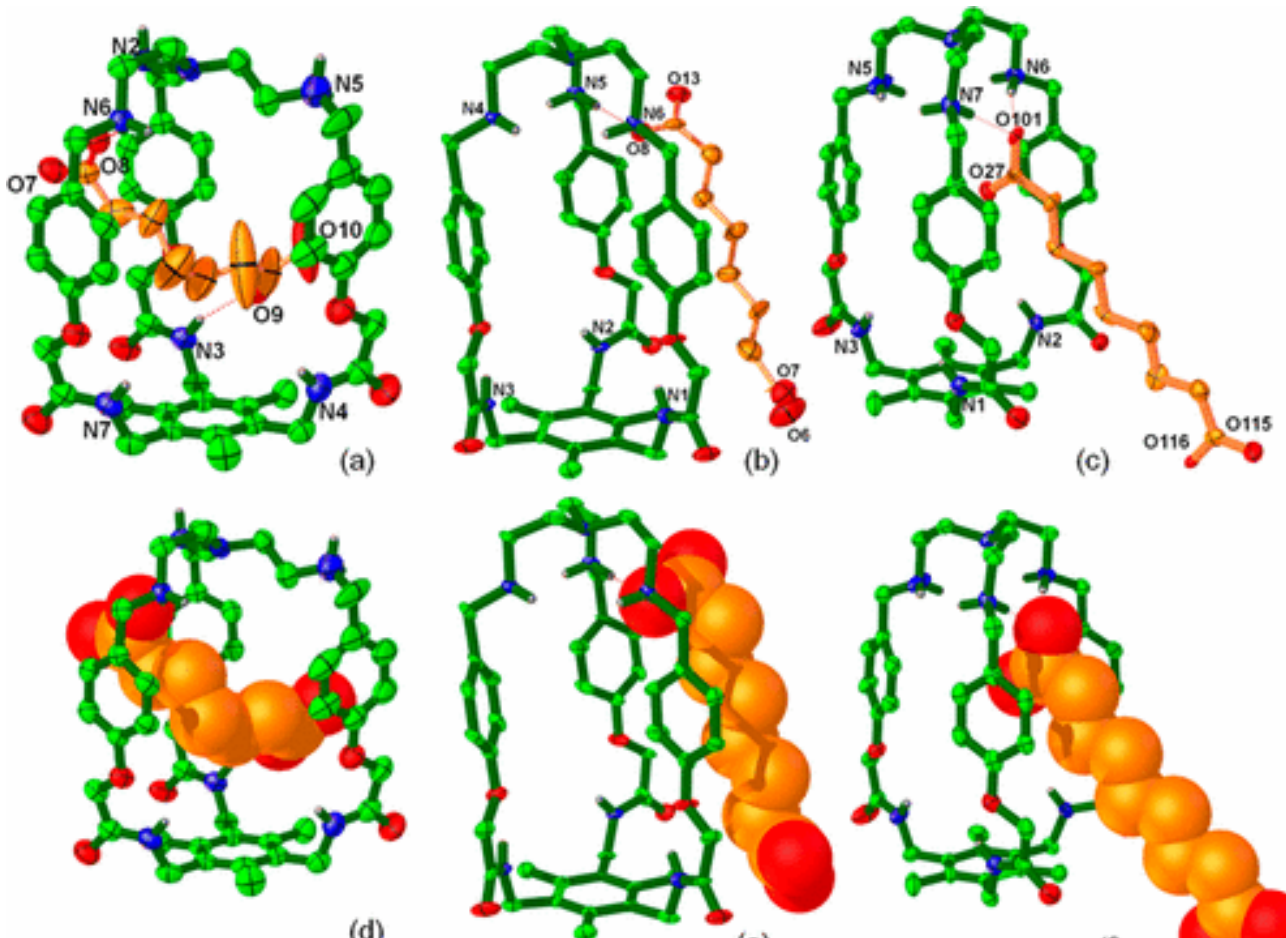

(e)

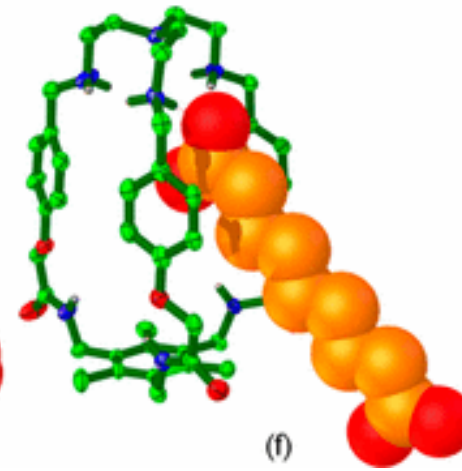

Figure 5. Single-crystal X-ray structures (in ellipsoid model) of complex (a) 4; one pimelate is in the cavity of $[\mathrm{H} 3 \mathrm{~L}] 3+$. Dicarboxylate guest and water molecules outside the receptor cavity are omitted for clarity. (b, c) 5 and 6 , in which dicarboxylate guests suberate and azelate are outside the cavity of $[H 3 L] 3+$, respectively. $(d-f)$ Guests are shown in space-filling representation, respectively. Only one dicarboxylate outside the cavity is shown. Water molecules outside the receptor cavity are also omitted for clarity.

The encapsulated pimelate ion is hydrogen bonded with amide (N6) and ammonium (N2) protons via $\mathrm{N}-\mathrm{H} \cdots \mathrm{O}$ interaction $[\mathrm{N} \cdots \mathrm{O}=2.738(7)-3.047(7) \AA \AA$ $\left.176^{\circ}\right]$. Interestingly, in complex 4 the pimelate is not fully encapsulated as its aliphatic chain is threaded into the cavity of $L$. This orientation is clearly due to the fact that the chain length of the dicarboxylate is above the length required to hold each carboxylate ends into the amide and ammonium clefts. However, the flexibility 
of the aliphatic chain of the guest allows their carboxylate functionalities to undergo hydrogen bonding interactions with both amide and ammonium protons in their semithreaded conformation into the receptor cavity.

Complex 5 crystallizes in a monoclinic P21/c space group. The asymmetric unit comprises one triprotonated receptor $[\mathrm{H} 3 \mathrm{~L}] 3+$, one molecule of methanol (encapsulated within the cavity of the receptor), two suberate anions and a lattice included water molecule. In complex 5, both dicarboxylate guests are outside the receptor cavity which is in contrast to the complexes 1 to 4 (Figure 5b, e). This observation further supports the requirements of an optimal chain length of the dicarboxylate to be encapsulated inside the receptor cavity. A similar observation is also found in the crystal structure of 6 , in which both of the azelates are located outside the receptor cavity (Figure 5c, f). As expected the receptor in both 5 and 6 exhibits various hydrogen bonding interactions with the guest anions and lattice included solvent molecules (Figures S20 and S21). Thus, the optimal length of a dicarboxylate guest (Table 2) to fit into the receptor cavity and to enjoy the strongest interactions with amide and ammonium clefts is observed in case of adipate, which is also reflected in the solution-state binding constant value.

Table 2. Comparison of Distances of 1-6 Obtained from X-ray Structural Analysis

Table 2. Comparison of Distances of 1-6 Obtained from X-ray Structural Analysis

\begin{tabular}{lccc}
\multicolumn{1}{c}{ guest } & chain length & $\begin{array}{c}\text { centroid.to-centroid distance between amide and amine } \\
\text { clefts }(A) \text { of the host }\end{array}$ & $\begin{array}{c}\text { distance between terminal carbons }(A) \text { of } \\
\text { the encapsulated dicarbonylate }\end{array}$ \\
\hline$a$-ketoglutarate & 5 & 8.67 & 5.06 \\
glutarate & 5 & 8.72 & 4.52 \\
adipate & 6 & 8.67 & 5.69 \\
pimelate & 7 & 8.66 & 6.39 \\
suberate & 8 & 8.32 & 8.84 \\
arelate & 9 & 8.69 & 10.27
\end{tabular}




\section{CONCLUSIONS}

The combination of amide and ammonium functionalities in an integrated hybrid receptor has shown interesting dicarboxylate binding phenomena by imposing hydrogen bonding and electrostatic interactions followed by aqueous solubility. The rigid framework and preorganization of the functional groups of the macrobicyclic receptor have an additional contribution for guest binding which is reflected in the single crystal X-ray structures as well as solution-state binding constants and in electrospray ionization mass spectrometry measurements which give evidence for the selective formation of $1: 1$ complexes. In fact, this study is the only one that provides a systematic series of binding constants along with the single-crystal X-ray structures of almost all the host-guest complexes. In particular, the investigated receptor performs chain-length-selective recognition of aliphatic dicarboxylate anions. Size and shape complementarities between the receptor and guest are essential ingredients for these kinds of ditopic guest binding, i.e., evidenced by the larger association constant value for adipate anion. Moreover, along with electrostatic forces, hydrogen bonding interactions are also contributing to the guest binding in highly competitive solvents like water and here we meet the challenge to bind highly hydrophilic guests in H2O/DMSO (50:50 v/v) medium. Thus, a novel generation of cagelike macrobicyclic receptors for dicarboxylate anions with polyamide functionalities as well as water-solubilizing polyammonium groups has been designed and studied for future applications. Efforts to extend the present approach are currently being pursued. 


\section{EXPERIMENTAL SECTION}

Macrobicycle, L was prepared by following a previously published procedure.(60)

\section{Syntheses of host-guest complexes 1-6}

Macrobicycle $\mathrm{L}(0.1 \mathrm{mmol}, 0.079 \mathrm{~g})$ was suspended in $10 \mathrm{~mL}$ of $\mathrm{CH} 3 \mathrm{OH} / \mathrm{H} 2 \mathrm{O}(9: 1)$ binary solvent mixture, and 3 equiv. $(0.3 \mathrm{mmol})$ of dicarboxylic acid were added to the stirred solution. The reaction mixture was stirred for another $2 \mathrm{~h}$. After that, the solution was filtered and stored at room temperature for crystallization to obtain complexes 1-6.

\section{H \& 13C NMR data of crystals of 1-6}

1: $1 \mathrm{H}$ NMR (300 MHz, DMSO-d6): $\delta$ (ppm) 2.34 (s, 9H, Ar-CH3), 2.54 (t, 6H, $\mathrm{NCH} 2 \mathrm{CH} 2 \mathrm{NH}$ ), 2.73-2.83 (t, 6H, NCH2CH2NH), 3.69 (s, 6H, Ar-CH2NH-CH2), 4.45 (s, 6H, - $\mathrm{COCH} 2 \mathrm{O}$ ), 4.48 (s, 6H, Ar-CH2NHCO), 6.86-6.87 (d, 6H, Ar-CH), 7.22-7.24 (d, 6H, Ar-CH), 7.35-7.37 (br, 3H, Ar-NHCO). The required peak for $-\mathrm{CH} 2$ of $\alpha$-keto glutarate may fall within the peak region for DMSO and thus not included. 13C NMR (75 MHz, DMSO-d6): 15.7, 27.7, 34.0, 37.2, 43.7, 50.3, 67.0, $114.7,130.4,132.6,136.5,156.9,166.5,168.2$, 173.9. Color, pale yellow; crystalline; yield, $0.041 \mathrm{~g} \mathrm{(35 \% ).}$

2: $1 \mathrm{H}$ NMR (300 MHz, DMSO-d6): $\delta$ (ppm) 1.66-1.72 (m, 6H, OOC-(CH2)3-COO), 2.19-2.22 (m, 12H, OOC-(CH2)3-COO), 2.35 (s, 9H, Ar-CH3), 2.44-2.50 (t, 6H, $\mathrm{NCH} 2 \mathrm{CH} 2 \mathrm{NH}$ ), 3.53 (s, 6H, Ar-CH2NH-CH2), 4.44 (s, 6H, -COCH2O), 4.49 (s, 6H, Ar-CH2NHCO), 6.83-6.85 (d, 6H, Ar-CH), 7.10-7.15 (d, 6H, Ar-CH), 7.27-7.29 (br,

3H, Ar-NHCO). 13C NMR (75 MHz, DMSO-d6): 15.7, 20.3, 33.3, 37.3, 46, 51.7, 
53.5, 67.2, 114.5, 129.3, 132.7, 136.4, 156.1, 166.7, 174.3. Color, pale white; crystalline; yield, $0.046 \mathrm{~g} \mathrm{(40 \% )}$.

3: 1H NMR (300 MHz, DMSO-d6): $\delta$ (ppm) 1.46-1.49 (m, 8H, OOC-(CH2)4-COO), 2.15-2.16 (m, 8H, OOC-(CH2)4-COO), 2.34 (s, 9H, Ar-CH3), 2.41-2.49 (t, 6H, $\mathrm{NCH} 2 \mathrm{CH} 2 \mathrm{NH}$ ), 3.52 (s, 6H, Ar-CH2NH-CH2), 4.42 (s, 6H, -COCH2O), 4.49 (s, 6H, Ar-CH2NHCO), 6.82-6.84 (d, 6H, Ar-CH), 7.11-7.13 (d, 6H, Ar-CH), 7.25-7.28 (br, 3H, Ar-NHCO). 13C NMR (75 MHz, DMSO-d6): 15.7, 24.2, 33.7, 37.3, 46.1, 51.9, 53.7, 67.2, 114.5, 129.2, 132.9, 136.5, 156.0, 166.7, 174.5. Color, yellow; crystalline; yield, $0.059 \mathrm{~g}(50 \%)$.

4: 1H NMR (300 MHz, DMSO-d6): $\delta$ (ppm) 1.24-1.28 (m, 2H, OOC-(CH2)5-COO), 1.46-1.52 (m, 4H, OOC-(CH2)5-COO), 2.16-2.19 (m, 4H, OOC-(CH2)5-COO), 2.36 (s, 9H, Ar-CH3), 2.42-2.43 (t, 6H, NCH2CH2NH), 3.54 (s, 6H, Ar-CH2NH-CH2), 4.43 (s, 6H, -COCH2O), 4.50-4.51 (s, 6H, Ar-CH2NHCO), 6.83-6.85 (d, 6H, Ar$\mathrm{CH}), 7.11-7.13$ (d, 6H, Ar-CH), 7.26-7.28 (br, 3H, Ar-NHCO). 13C NMR (75 MHz, DMSO-d6): 15.7, 24.3, 28.1, 33.8, 37.3, 46.6, 52.1, 54.1, 67.2, 114.5, 128.9, 132.7, 133.5, 136.4, 155.9, 166.7, 174.5. Color, white; crystalline; yield, $0.053 \mathrm{~g}(42 \%)$.

5: 1H NMR (500 MHz, DMSO-d6): $\delta$ (ppm) 1.25 (m, 9H, OOC-(CH2)6-COO), 1.45$1.48(\mathrm{~m}, 8 \mathrm{H}, \mathrm{OOC}-(\mathrm{CH} 2) 6-\mathrm{COO}), 2.16-2.17$ (m, 8H, OOC-(CH2)6-COO), 2.35 (s, 9H, Ar-CH3), 2.41-2.49 (m, 6H, NCH2CH2NH), 3.53 (s, 6H, Ar-CH2NH-CH2), 4.42 (s, 6H, -COCH2O), 4.49-4.50 (d, 6H, Ar-CH2NHCO), 6.82-6.84 (d, 6H, Ar-CH), 7.11-7.12 (d, 6H, Ar-CH), 7.25-7.27 (br, 3H, Ar-NHCO). 13C NMR (75 MHz, DMSO-d6): 15.7, 24.4, 28.2, 33.8, 37.3, 38.9, 46.3, 52.0, 53.9, 67.2, 114.5, 129.1, 132.7, 133.1, 136.4, 156.0, 166.7, 174.6. Color, dark yellow; crystalline; yield, 0.038 $g(30 \%)$. 
6: 1H NMR (300 MHz, DMSO-d6): $\delta(p p m) 1.24$ (m, 16H, OOC-(CH2)7-COO) 1.45$1.48(\mathrm{~m}, 8 \mathrm{H}, \mathrm{OOC}-(\mathrm{CH} 2) 7-\mathrm{COO}), 2.15-2.19(\mathrm{~m}, 8 \mathrm{H}, \mathrm{OOC}-(\mathrm{CH} 2) 7-\mathrm{COO}), 2.34$ (s, 9H, Ar-CH3), 2.41 (b, 6H, NCH2CH2NH), 3.51 (s, 6H, $\mathrm{Ar}-\mathrm{CH} 2 \mathrm{NH}-\mathrm{CH} 2), 4.41$ (s, $6 \mathrm{H},-\mathrm{COCH} 2 \mathrm{O}$ ), 4.48-4.49 (d, 6H, Ar-CH2NHCO), 6.81-6.83 (d, 6H, Ar-CH), 7.097.11 (d, 6H, Ar-CH), 7.24-7.26 (br, 3H, Ar-NHCO). 13C NMR (75 MHz, DMSO-d6): $15.7,24.4,28.4,33.7,37.3,46.5,52.1,53.7,67.2,114.5,129.0,132.7,136.4$, 156.0., 166.7, 174.5. Color, pale yellow; crystalline; yield, $0.067 \mathrm{~g}(50 \%)$.

\section{Single-Crystal X-ray Structural Studies Details}

For each complex, a crystal of suitable size is collected from the mother liquor and is dipped in paratone oil, then mounted on the tip of a glass fiber and cemented using epoxy resin. Intensity data for all crystals are collected using MoKa $(\lambda=0.7107 \AA)$ radiation on a Bruker SMART APEX diffractometer equipped with a CCD area detector at 120 or $150 \mathrm{~K}$. The data integration and reduction are processed with SAINT software. An empirical absorption correction is applied to the collected reflections with SADABS. The structures are solved by direct methods using SHELXTL and are refined on F2 by the full-matrix least-squares technique using the SHELXL-97 program package. Graphics are generated using OLEX PLATON and MERCURY 3.5. All the $\mathrm{N}-\mathrm{H}$ and $\mathrm{C}-\mathrm{H}$ protons of the protonated macrobicyclic cage are geometrically fixed and are refined isotropically. The hydrogen atoms of the water molecules have not been located in the electron Fourier map. In complex 2, the glutarate anions are disordered and were treated as two position disorder by using PART, SAME and second free variable (FVAR) commands of SHELXL. The site occupancy factor (sof) associated with these disordered atoms of glutarate anions were fixed by using 21.000 and $-21.000,31.000$, and -31.000 . FVAR kept as 0.5 (arbitrary) for all the cases and refined. Further refinement cycles revealed the 
real sof of the disordered atoms of glutarate anions as (0.56372 and 0.43628$)$, and (0.49985 and 0.50015).

\section{Potentiometric studies}

\section{Equipment and experimental conditions}

The potentiometric setup for a typical titration consisted of a $50 \mathrm{~mL}$ glass-jacketed cell sealed from the atmosphere, connected to a separate glass-jacketed reference electrode cell by a Wilhelm type salt bridge containing $0.10 \mathrm{M} \mathrm{KNO3}$ solution. An Orion SA720 measuring instrument fitted with a Metrohm 6.0150.100 glass electrode and a Metrohm 6.0733.100 $\mathrm{Ag} / \mathrm{AgCl}$ reference electrode was used for the measurements. The temperature was kept at $298.2 \pm 0.1 \mathrm{~K}$ using a PolyScience910 thermostat. Atmospheric $\mathrm{CO} 2$ was excluded from the titration cell by a continuous nitrogen flux. Titrant solutions were added through capillary tips at the surface of the experimental solution by a Metrohm Dosimat 665 automatic buret. The titration procedure is automatically controlled by software.(63) The titrant was an aqueous $\mathrm{KOH}$ solution prepared at about $0.100 \mathrm{M}$ from a commercial ampule of analytical grade, and its accurate concentration was obtained by application of the Gran's method.(64) All other analytical solutions were prepared in H2O-DMSO (50:50 v/v) mixed solvent. Anion solutions were prepared at $0.01-0.025 \mathrm{M}$ from the corresponding acids immediately before use. A receptor solution was prepared at about $5.0 \times 10-4 \mathrm{M}$ by addition of approximately 5 equiv of $\mathrm{HClO} 4$ to L. Sample solutions for the $\mathrm{L}$ titrations contained approximately $0.02 \mathrm{mmol}$ of ligand in a total volume of $40 \mathrm{~mL}$, while solutions for the anion titrations contained approximately $0.05 \mathrm{mmol}$ of anion in a total volume of $20 \mathrm{~mL}$. The accurate concentrations of the 
receptor and anions solutions were determined by acid-base titrations. All titrations contained $\mathrm{NaClO} 4$ as background electrolyte. The glass electrode was conditioned by soaking it in H2O-DMSO (50:50 v/v) solution for a period of 3 days and was afterward kept in the same mixture, in order to prevent erratic responses.

\section{Measurements}

All measurements were carried out at $25.0 \pm 0.1^{\circ} \mathrm{C}$ under inert atmosphere with the ionic strength kept at $0.10 \pm 0.01 \mathrm{M}$ with $\mathrm{NaClO} 4$ in $\mathrm{H} 2 \mathrm{O}-\mathrm{DMSO}(50: 50 \mathrm{v} / \mathrm{v})$ solvent mixture. Prior to each titration, the electrode response of the setup was calibrated by titration of a standard HNO3 solution in the same experimental conditions. The $[\mathrm{H}+]$ of the experimental solutions was determined by measurement of the electromotive force of the cell, $E=E o^{\prime}+Q \log [H+]+E j$. The term $p H$ is defined as $-\log [H+]$. Eo' and $\mathrm{Q}$ were determined from the acid region of the calibration titrations. The liquidjunction potential Ej was found to be negligible under the experimental conditions used. The value of $\mathrm{Kw}=[\mathrm{H}+][\mathrm{OH}-]$ was found to be equal to $1 \times 10-15.30$ from the alkaline $\mathrm{pH}$ region of the calibration titrations, considering Eo' and $\mathrm{Q}$ valid for the entire $\mathrm{pH}$ range. Each titration consisted of $80-100$ equilibrium points in the range of $\mathrm{pH} 3-12$. Titrations of the $\mathrm{L}$ receptor in the presence of each anion contained 3 equiv of the anion relative to the ligand amount.

\section{Calculations}

The potentiometric data were refined with the Hyperquad 2008 software.(65) Speciation and Keff diagrams were plotted using the HySS software.(66) Data 
refinement was done in the form of the overall equilibrium constants $\mathrm{\beta iH}$ and $\beta \mathrm{HhLAa}$ defined by $\beta \mathrm{iH}=[\mathrm{HiL}] /[\mathrm{H}] \mathrm{i}[\mathrm{L}]$ and $\beta \mathrm{HhLAa}=[\mathrm{HhLAa}] /[\mathrm{H}] \mathrm{h}[\mathrm{L}][\mathrm{A}] \mathrm{a}$. The errors quoted are the standard deviations calculated by the fitting program from all the experimental data for each system. The species considered in each particular system were those that could be justified by the principles of supramolecular chemistry. Stepwise association constants KHhLA for each system were then calculated from the overall association constants by taking into account the relevant species equilibria.

\section{Mass spectrometry}

\section{Electrospray-Ionization Mass Spectrometry (ESI-MS)}

Electrospray ionization quadrupole-time-of-flight high resolution mass spectrometric (ESI-Q-TOF-HRMS) experiments were performed with a Synapt G2-S HDMS (Waters Co., Milford, MA, USA) instrument. The flow rate was set to $10 \mathrm{~mL} \mathrm{~min}-1$, the spray voltage to $1.87 \mathrm{kV}$, the sample cone voltage to $33 \mathrm{~V}$, the source offset to $47 \mathrm{~V}$, the source temperature to $90^{\circ} \mathrm{C}$, the desolvation temperature to $300{ }^{\circ} \mathrm{C}$, the nebulizer gas to 6 bar and the desolvation gas flow to $565 \mathrm{~L} \mathrm{h-1}$. Samples were prepared by mixing equimolar solutions of the receptor $L$ and the corresponding acid and diluting to obtain $100 \mu \mathrm{M}$ solutions in $\mathrm{H} 2 \mathrm{O} / \mathrm{MeOH} / \mathrm{CH} 2 \mathrm{Cl} 2$ 95:4:1.

\section{Traveling-Wave lon Mobility-Mass Spectrometry (TW-IMS)}

TW-IMS experiments were performed with a Synapt G2-S HDMS (Waters Co., Milford, MA, USA) instrument. The T-wave velocity was set to $10.6 \mathrm{~m} \mathrm{~s}-1$, the T- 
wave peak height to $34.6 \mathrm{~V}$, the nitrogen gas flow in the T-wave mobility cell to 89.2 $\mathrm{mL} / \mathrm{min}$. Data acquisition and processing were carried out using the Waters Driftscope (version 2.6) software and MassLynxTM (version 4.1). The sample solution containing all complexes was prepared by mixing equimolar solutions of the receptor $L$ (8 equiv.) and the corresponding acids (1 equiv. each) and diluting to obtain a $30 \mu \mathrm{M}$ solution in $\mathrm{H} 2 \mathrm{O} / \mathrm{MeOH} / \mathrm{CH} 2 \mathrm{Cl} 2$ 95:4:1.

\section{ACKNOWLEDGMENT}

P.G. gratefully acknowledges the Science and Engineering Research Board (SERB), New Delhi (project SR/S1/IC-39/2012), for financial support. S.C., S.

Saha, and B.A. thank the IACS, Kolkata, India, for fellowships. S. Sarkar and S.B. are thankful to CSIR, India, for fellowships, and M.N. is thankful to DSTINSPIRE, India, for a fellowship. L.M.P.L. and R.D. are grateful for financial support from project LISBOA-01-0145-FEDER-007660 (Microbiologia Molecular, Estrutural e Celular) funded by FEDER funds through COMPETE2020 - Programa Operacional Competitividade e Internacionalização $(\mathrm{POCl})$ and by national funds through FCT (Fundação para a Ciência e a Tecnologia). L.M.P.L. acknowledges FCT for a postdoctoral fellowship (SFRH/BPD/73361/2010). C.A.S. and U.W. thank the Deutsche Forschungsgemeinschaft for financial support (CRC 765). X-ray crystallographic studies were performed at the DST-funded National SingleCrystal X-ray Diffraction Facility at the Department of Inorganic Chemistry, IACS. 


\section{REFERENCES}

1Bianchi, A.; Bowman-James, K.; Garcia-Espana, E. Supramolecular Chemistry of Anions; Wiley-VCH, Weinheim, Germany, 1997.Google Scholar

2Gale, P. A.; Quesada, R. Coord. Chem. Rev. 2006, 250, 3219DOI: 10.1016/j.ccr.2006.05.020

3Gale, P. A. Chem. Soc. Rev. 2010, 39, 3746DOI: 10.1039/c001871f

4Hargrove, A. E.; Nieto, S.; Zhang, T.; Sessler, J. L.; Anslyn, E. V. Chem. Rev. 2011, 111, 6603DOI: $10.1021 / \mathrm{cr} 100242 \mathrm{~s}$

5Curiel, D.; Más-Montoya, M.; Sánchez, G. Coord. Chem. Rev. 2015, 284, 19DOI: 10.1016/j.ccr.2014.09.010

6Linton, B. R.; Goodman, M. S.; Fan, E.; van Arman, S. A.; Hamilton, A. D. J. Org. Chem. 2001, 66, 7313DOI: 10.1021/jo010413y

7Filby, M. H.; Humphries, T. D.; Turner, D. R.; Kataky, R.; Kruusma, J.; Steed, J. W. Chem. Commun. 2006, 156DOI: 10.1039/B512779C

8González-Álvarez, A.; Alfonso, I.; Díaz, P.; García-España, E.; Gotor-Fernández, V.; Gotor, V. J. Org. Chem. 2008, 73, 374DOI: 10.1021/j0701636b

9Arbuse, A.; Anda, C.; Martínez, M. A.; Pérez-Mirón, J.; Jaime, C.; Parella, T.; Llobet, A. Inorg. Chem. 2007, 46, 10632DOI: 10.1021/ic701288n

10Anda, C.; Llobet, A.; Martell, A. E.; Reibenspies, J.; Berni, E.; Solans, X. Inorg. Chem. 2004, 43, 2793DOI: 10.1021/ic035121p

11Ghosh, K.; Masanta, G.; Fröhlich, R.; Petsalakis, I. D.; Theodorakopoulos, G. J. Phys. Chem. B 2009, 113, 7800DOI: 10.1021/jp901151w

12Hof, F.; Diederich, F. Chem. Commun. 2004, 477DOI: 10.1039/b314081b

13Hosseini, M. W.; Lehn, J.-M. Helv. Chim. Acta 1986, 69, 587DOI: 10.1002/hlca.19860690308

14Hosseini, M. W.; Lehn, J. M. J. Am. Chem. Soc. 1982, 104, 3525DOI: 10.1021/ja00376a056

15Goswami, S.; Ghosh, K.; Dasgupta, S. J. Org. Chem. 2000, 65, 1907DOI: $10.1021 /$ jo9909204

16Kim, D.-S.; Miyaji, H.; Chang, B.-Y.; Park, S.-M.; Ahn, K. H. Chem. Commun. 2006, 3314DOI: 10.1039/b606081a

17Zeng, Z.-Y.; He, Y.-B.; Wu, J.-L.; Wei, L.-H.; Liu, X.; Meng, L.-Z.; Yang, X. Eur. J. Org. Chem. 2004, 2004, 2888DOI: 10.1002/ejoc.200400014 [Crossref], Google Scholar

18Ghosh, K.; Masanta, G.; Chattopadhyay, A. P. Eur. J. Org. Chem. 2009, 2009, 4515DOI: 10.1002/ejoc.200900471 [Crossref], Google Scholar

19Liu, S.-Y.; Fang, L.; He, Y.-B.; Chan, W.-H.; Yeung, K.-T.; Cheng, Y.-K.; Yang, R.-H. Org. Lett. 2005, 7, 5825DOI: 10.1021/ol052341t 
20Boiocchi, M.; Bonizzoni, M.; Moletti, A.; Pasini, D.; Taglietti, A. New J. Chem. 2007, 31, 352DOI: $10.1039 / \mathrm{b} 616492 \mathrm{~g}$

21Sebo, L.; Schweizer, B.; Diederich, F. Helv. Chim. Acta 2000, 83, 80DOI: 10.1002/(SICI)1522-2675(20000119)83:1<80::AID-HLCA80>3.0.CO;2-P

22Kusukawa, T.; Toyama, K.; Takeshita, S.; Tanaka, S. Tetrahedron 2012, 68, 9973DOI: 10.1016/j.tet.2012.09.072

23Jadhav, J. R.; Ahmad, M. W.; Kim, H.-S. Tetrahedron Lett. 2010, 51, 5954DOI: 10.1016/j.tetlet.2010.09.030

24Ghosh, K.; Saha, I.; Masanta, G.; Wang, E. B.; Parish, C. A. Tetrahedron Lett. 2010, 51, 343DOI: 10.1016/j.tetlet.2009.11.021

25Liu, S.-Y.; He, Y.-B.; Chan, W. H.; Lee, A. W. M. Tetrahedron 2006, 62, 11687DOI: 10.1016/j.tet.2006.09.042

26Carvalho, S.; Delgado, R.; Fonseca, N.; Félix, V. New J. Chem. 2006, 30, 247DOI: $10.1039 / \mathrm{b} 512661 \mathrm{~d}$

27Kang, S.-O.; Llinares, J. M.; Day, V. W.; Bowman-James, K. Chem. Soc. Rev. 2010, 39, 3980DOI: 10.1039/c0cs00083c

28Ballester, P. Chem. Soc. Rev. 2010, 39, 3810DOI: 10.1039/b926229f

29Belen Jimenez, M.; Alcazar, V.; Pelaez, R.; Sanz, F.; Fuentes de Arriba, A. L.; Caballero, M. C. Org. Biomol. Chem. 2012, 10, 1181DOI: 10.1039/C1OB06540H

30Mateus, P.; Delgado, R.; Brandão, P.; Félix, V. Org. Biomol. Chem. 2012, 10, 5529DOI: $10.1039 / c 20 b 25725 d$

31Steed, J. W. Chem. Commun. 2006, 2637DOI: 10.1039/b601511e

32Saeed, M. A.; Fronczek, F. R.; Huang, M.-J.; Alamgir Hossain, M. Chem. Commun. 2010, 46, 404DOI: 10.1039/B923013K

33McKee, V.; Nelson, J.; Town, R. M. Chem. Soc. Rev. 2003, 32, 309DOI: $10.1039 / \mathrm{b} 200672 \mathrm{n}$

34Kang, S. O.; Hossain, M. A.; Bowman-James, K. Coord. Chem. Rev. 2006, 250, 3038DOI: 10.1016/j.ccr.2006.06.006

35llioudis, C. A.; Tocher, D. A.; Steed, J. W. J. Am. Chem. Soc. 2004, 126, 12395DOI: $10.1021 / \mathrm{ja0} 047070 \mathrm{~g}$

36Deetz, M. J.; Shang, M.; Smith, B. D. J. Am. Chem. Soc. 2000, 122, 6201DOI: 10.1021/ja994487r

37llioudis, C. A.; Steed, J. W. J. Supramol. Chem. 2001, 1, 165DOI: 10.1016/S14727862(02)00026-6

38Lehn, J.-M.; Meric, R.; Vigneron, J.-P.; Bkouche-Waksman, I.; Pascard, C. J. Chem. Soc., Chem. Commun. 1991, 62DOI: 10.1039/C39910000062

39Teulade-Fichou, M.-P.; Vigneron, J.-P.; Lehn, J.-M. J. Chem. Soc., Perkin Trans. 2 1996, 2169DOI: $10.1039 / p 29960002169$ 
40Mateus, P.; Delgado, R.; Brandão, P.; Félix, V. J. Org. Chem. 2012, 77, 4611DOI: 10.1021/j0300320w

41Llinares, J. M.; Powell, D.; Bowman-James, K. Coord. Chem. Rev. 2003, 240, 57DOI: 10.1016/S0010-8545(03)00019-5

42Nelson, J.; Nieuwenhuyzen, M.; Pal, I.; Town, R. M. Dalton Trans. 2004, 229DOI: 10.1039/B311379E

43Nelson, J.; Nieuwenhuyzen, M.; Pal, I.; Town, R. M. Chem. Commun. 2002, 2266DOI: 10.1039/B207964J

44Mateus, P.; Delgado, R.; Brandão, P.; Félix, V. Chem. - Eur. J. 2011, 17, 7020DOI: 10.1002/chem.201100428

45Llinares, J. M.; Powell, D.; Bowman-James, K. Coord. Chem. Rev. 2003, 240, 57DOI: 10.1016/S0010-8545(03)00019-5

46Boiocchi, M.; Bonizzoni, M.; Fabbrizzi, L.; Piovani, G.; Taglietti, A. Angew. Chem., Int. Ed. 2004, 43, 3847DOI: 10.1002/anie.200460036

47Mateus, P.; Lima, L. M. P.; Delgado, R. Polyhedron 2013, 52, 25DOI: 10.1016/j.poly.2012.07.073

48Mateus, P.; Delgado, R.; André, V.; Duarte, M. T. Inorg. Chem. 2015, 54, 229DOI: 10.1021/ic502230q

49Kang, S. O.; Hossain, M. A.; Bowman-James, K. Coord. Chem. Rev. 2006, 250, 3038DOI: 10.1016/j.ccr.2006.06.006

50Kang, S. O.; Begum, R. A.; Bowman-James, K. Angew. Chem., Int. Ed. 2006, 45, 7882DOI: 10.1002/anie.200602006

51Bondy, C. R.; Loeb, S. J. Coord. Chem. Rev. 2003, 240, 77DOI: 10.1016/S00108545(02)00304-1

52Arunachalam, M.; Ghosh, P. Org. Lett. 2010, 12, 328DOI: 10.1021/ol9026649

53Lakshminarayanan, P. S.; Suresh, E.; Ghosh, P. Inorg. Chem. 2006, 45, 4372DOI: 10.1021/ic052159o

54Kang, S. O.; Powell, D.; Bowman-James, K. J. Am. Chem. Soc. 2005, 127, 13478DOI: 10.1021/ja054332I

55Kang, S. O.; Day, V. W.; Bowman-James, K. Org. Lett. 2009, 11, 3654DOI: $10.1021 / 019014249$

56Kral, V.; Andrievsky, A.; Sessler, J. L. J. Am. Chem. Soc. 1995, 117, 2953DOI: 10.1021/ja00115a041

57Wang, Q.-Q.; Day, V. W.; Bowman-James, K. Chem. Sci. 2011, 2, 1735DOI: $10.1039 / \mathrm{c} 1 \mathrm{sc} 00292 \mathrm{a}$

58Kang, S. O.; Day, V. W.; Bowman-James, K. Org. Lett. 2008, 10, 2677DOI: 10.1021/ol800762j

59Cafeo, G.; Gattuso, G.; Kohnke, F. H.; Papanikolaou, G.; Profumo, A.; Rosano, C. Chem. - Eur. J. 2014, 20, 1658DOI: 10.1002/chem.201303265 
60Saha, S.; Akhuli, B.; Chakraborty, S.; Ghosh, P. J. Org. Chem. 2013, 78, 8759DOI: 10.1021/j0401504f

61Albelda, M. T.; Bernardo, M. A.; Garcia-España, E.; Godino-Salido, M. L.; Luis, S. V.; Melo, M. J.; Pina, F.; Soriano, C. J. Chem. Soc., Perkin Trans. 2 1999, 2545DOI: 10.1039/a904894d

62Mateus, P.; Delgado, R.; André, V.; Duarte, M. T. Org. Biomol. Chem. 2015, 13, 834DOI: 10.1039/C4OB02027H

63Esteves, C. V.; Mateus, P.; André, V.; Bandeira, N. A. G.; Calhorda, M. J.; Ferreira, L. P.; Delgado, R. Inorg. Chem. 2016, 55, 7051DOI: 10.1021/acs.inorgchem.6b00945

64Rossotti, F. J. C.; Rossotti, H. J. Chem. Educ. 1965, 42, 375DOI: 10.1021/ed042p375

65Gans, P.; Sabatini, A.; Vacca, A. Talanta 1996, 43, 1739DOI: 10.1016/00399140(96)01958-3

66Alderighi, L.; Gans, P.; lenco, A.; Peters, D.; Sabatini, A.; Vacca, A. Coord. Chem. Rev. 1999, 184, 311 